\title{
Current radiological situation in Slavonski Brod, Croatia: is there a reason for concern?
}

\author{
Branko Petrinec ${ }^{1}$, Isabela Tišma ${ }^{2}$, Marko Šoštarić1, Marina Poje Sovilj², Dinko Babić1 ${ }^{1}$, Vanja \\ Radolić ${ }^{2}$, Igor Miklavčić ${ }^{2}$, and Branko Vuković ${ }^{2}$ \\ Institute for Medical Research and Occupational Health, Zagreb ${ }^{1}$, J. J. Strossmayer University in Osijek, \\ Department of Physics, Osijek², Croatia
}

[Received in May 2017; Similarity Check in May 2017; Accepted in July 2017]

For years, the town of Slavonski Brod in Croatia has been facing serious problems with air pollution, which is usually attributed to an oil refinery across the Sava River in Bosnia and Herzegovina. While the air quality is being monitored rigorously with regard to nonradioactive matter, no attention has been paid to the possibility of a coincidental radioactive pollution. This study is the first to have addressed this issue. We measured ambient dose rate equivalents at 150 sites and found that none exceeded $120 \mathrm{nSv} \mathrm{h}^{-1}$, while the average was $80 \mathrm{nSv} \mathrm{h}^{-1}$. Gamma-ray spectrometry of the collected river water and soil samples did not reveal any unusual radioactivity either. In other words, we have found no evidence of radioactive pollution that would endanger the health of the residents of Slavonski Brod.

KEY WORDS: air quality; ambient dose rate equivalent; gamma ray spectrometry; oil refinery; radioactive pollution

Slavonski Brod is a Croatian town of 65,000 residents, situated on the left bank of the Sava River at the border with Bosnia and Herzegovina (Figure 1). Just across the border, there is an old oil refinery owned by an investor from a non-EU country. For several years, the residents of Slavonski Brod have been complaining about the quality of air, and many point to the refinery as the source of pollution. The issue has eventually become politicised, the argument being that every EU citizen has the right to live in a clean environment.

Annual air quality monitoring reports from 2015 on (1-3) show that these complaints have been justified. In 2014, the air was heavily polluted with $\mathrm{H}_{2} \mathrm{~S}$, whereas the levels of $\mathrm{C}_{6} \mathrm{H}_{6}, \mathrm{NO}_{2}, \mathrm{SO}_{2}$, and fine particulate matter $\mathrm{PM}_{2.5}$ (particle diameter $<2.5 \mu \mathrm{m}$ ) were satisfactory (1). In 2015, $\mathrm{H}_{2} \mathrm{~S}$ pollution continued, and $\mathrm{PM}_{10}$ levels frequently exceeded the allowed daily limit (2). In 2016, the situation with $\mathrm{H}_{2} \mathrm{~S}$ and $\mathrm{PM}_{10}$ was even worse (3).

Scientific involvement in this problem has been surprisingly scarce and limited to the pollutants mentioned above (4) considering that oil refining industry involves the risk of a radioactive contamination with waste (e.g., sludge, spent process catalysts, filter clay, etc.) (5). Moreover, airborne radionuclides in the plant exhaust gasses may pollute nearby areas. The old refinery processes oil of unknown purity, and the ongoing debate on the pollution causes is in large part focused on this issue.

Correspondence to: Marko Šoštarić, Institute for Medical Research and Occupational Health, Ksaverska cesta 2, HR-10000 Zagreb;

E-mail:msostaric@imi.hr
The aim of our study, however, was not to identify the source of the pollution or enter the debate about its social or political connotations. Instead, we wanted to see if the observed air pollution was accompanied by an increase in the concentrations of radionuclides in the environment and, therefore, provide relevant scientific data about one environmental aspect of a town that seems to have become a burning health risk issue not only in Croatia but also in the EU.

\section{MATERIALS AND METHODS}

We measured ambient dose rate equivalent $\dot{H}^{*}(10)$ at 150 locations and sampled soil at four locations in Slavonski Brod. Soil was also sampled at three locations outside Slavonski Brod. We took samples of water from the Sava River in Slavonski Brod as well as upstream and downstream. The soil and river water samples were used for gamma-ray spectrometry, which allows us to identify whether there are any significant deviations from the trends known from our monitoring of environmental radioactivity in Croatia (6-9). From the activity concentration data we calculated several radiological parameters. First we assessed the $\dot{H}^{*}(10)$ and the absorbed dose rate $\dot{D}$ originating from the activity of radionuclides in soil, which we then compared with the measured values. We also calculated the related radium equivalent activity and external hazard index.

$\dot{H}^{*}(10)$ in the range from $10 \mathrm{nSv} \mathrm{h}^{-1}$ to $0.1 \mathrm{~Sv} \mathrm{~h}^{-1}$ (with a resolution of $10 \mathrm{nSv} \mathrm{h}^{-1}$ ) was determined from photon energies between $48 \mathrm{keV}$ and $3 \mathrm{MeV}$ identified with a 


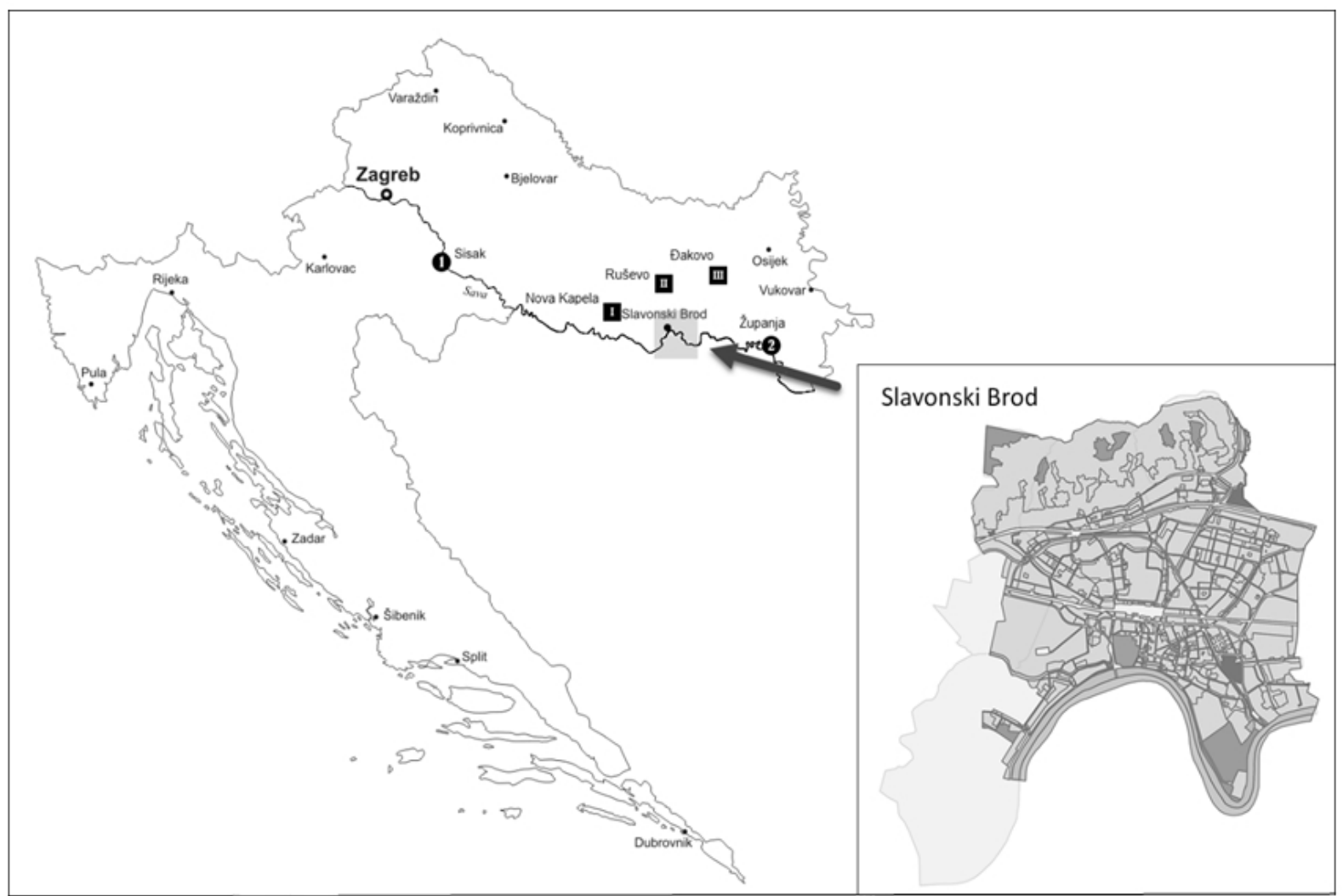

Figure 1 Slavonski Brod on the map of Croatia; I, II, and III denote additional soil sampling locations in the neighbourhood; 1 and 2 - additional Sava River water sampling locations (Sisak and Županja)

Mirion Technologies (San Roman, CA, USA) RDS-31 S/R multi-purpose survey meter (10). This energy range covers most of the gamma-ray emissions by naturally occurring and fission-produced radionuclides (those with lower energies contribute little to the total dose), and the resolution is sufficient for detecting any significant departure from the usual trends. The measurements took place at 150 locations (Figure 2, marked by solid triangles) over July and August 2016. In order to minimise the influence of local meteorological conditions, the recordings were always made in the shade at $1 \mathrm{~m}$ above the ground on sunny, windless days. Measuring at $1 \mathrm{~m}$ made it possible to estimate the contribution of soil to $\dot{H}^{*}(10)$ from the models that correlate activity concentrations in the soil and gamma ray fields above the ground. Each measurement took 15 minutes to obtain a reliable reading, whose error depended on the resolution of the instrument.

The river water and soil samples were collected following the IAEA recommendations $(11,12)$. The Sava River water was sampled not only in Slavonski Brod but also downstream in Županja and upstream in Sisak (designated as 1 and 2 in Figure 1) in September and October 2016. The topmost 10-cm layer of soil was sampled at four locations in Slavonski Brod in September 2016 (Figure 2, marked by solid squares 1-4). For comparison, we also sampled soil at three locations (designated as I, II, and III in Figure 1) in the same area but tens of kilometres away from Slavonski Brod.
In order to increase the radionuclide concentrations in a measurement volume, we evaporated about $50 \mathrm{~L}$ of water to the volume of $1 \mathrm{~L}$ and then poured it into a Marinelli beaker.

Soil was dried and sieved before being packed and sealed in a $100 \mathrm{~mL}$ container and left to rest before establishing the secular equilibria in the uranium and thorium decay chains. Samples prepared in this way were used to measure activity concentrations with an ORTEC gamma-ray spectrometry system based on a high purity $\mathrm{Ge}$ coaxial GMX-type detector (relative efficiency of $74.2 \%$ and peak full width at half maximum of $2.24 \mathrm{keV}$, all at $1.33 \mathrm{MeV}{ }^{60} \mathrm{Co}$ ). For energy and efficiency calibrations we used certified calibration sources obtained from the Czech Metrology Institute. Necessary quality assurance procedures in measurements and analysis were applied (13), most notably those regarding corrections for the self-attenuation (14) and true coincidence (15) effects.

\section{RESULTS AND DISCUSSION}

\section{Ambient dose rate equivalent}

The locations where we measured $\dot{H}^{*}(10)$ covered most of the urban area and a part of the left Sava River bank close to the refinery. The dark grey areas in Figure 2 mark the measurement range $90 \mathrm{nSv} \mathrm{h}^{-1}<\dot{H}^{*}(10)<120 \mathrm{nSv} \mathrm{h}^{-1}$, and the light grey areas $50 \mathrm{nSv} \mathrm{h} \mathrm{h}^{-1}<\dot{H}^{*}(10)<90 \mathrm{nSv} \mathrm{h}^{-1}$. The 

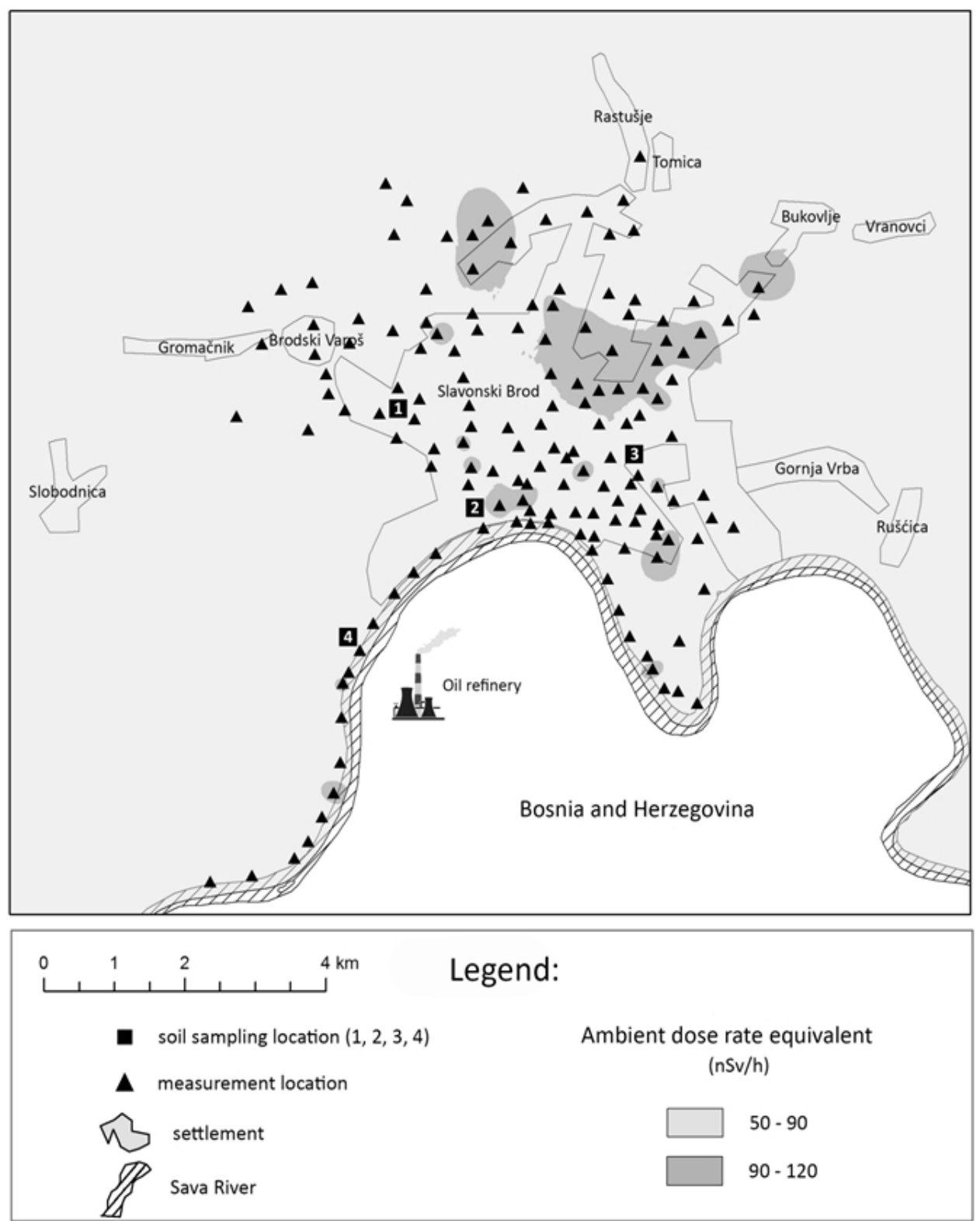

Figure 2 Measurement locations, soil sampling sites, and the distribution of $\dot{H}^{*}(10)$ on the map of Slavonski Brod. The position of the oil refinery is also shown

mean of all 150 measurement sites was $\dot{H}^{*}(10)=80 \pm 15 \mathrm{nSvh}^{-1}$. This is similar to the $\dot{H}^{*}(10)$ monitoring data for Croatia in 2016, where the averages of 14 locations ranged between 77 and $120 \mathrm{nSv} \mathrm{h}^{-1}(6-9)$. In other words, we found no evidence of $\dot{H}^{*}(10)$ exceeding the Croatian averages.

\section{Activity concentrations in soil and river water}

Table 1 shows the activity concentrations A of ${ }^{40} \mathrm{~K},{ }^{137} \mathrm{Cs}$, ${ }^{232} \mathrm{Th},{ }^{238} \mathrm{U},{ }^{226} \mathrm{Ra}$, and ${ }^{210} \mathrm{~Pb}$ in the surface soil samples. The comparison with non-urban samples (I-III) shows that the activity concentrations in urban samples 1-4 are not elevated.

All three Sava River samples contained ${ }^{40} \mathrm{~K}$, two contained ${ }^{137} \mathrm{Cs}$ (Sisak and Slavonski Brod, about $1 \mathrm{~Bq} \mathrm{~m}^{-3}$ each), whereas the activity concentrations of ${ }^{232} \mathrm{Th},{ }^{238} \mathrm{U}$, ${ }^{226} \mathrm{Ra}$, and ${ }^{210} \mathrm{~Pb}$ were below the detection limit.

In other words, we found no elevated levels of radioactivity in the soil and the Sava River water in Slavonski Brod.

\section{Radiological risk parameters}

Based on the activity concentrations we assessed how much the soil contributed to the measured $\dot{H}^{*}(10)$. This way we could infer the contribution of air radioactivity, which was not sampled in this study. As the $A$ of ${ }^{137} \mathrm{Cs}$ was rather small (Table 1), we focused on the activity concentrations of the naturally occurring radionuclides. The rate $\dot{E}$ of gamma-ray energy fields per unit mass at $1 \mathrm{~m}$ 
Table 1 Activity concentration in soil samples. Locations 1-4 and I-III are shown in Figures 2 and 1, respectively.

\begin{tabular}{ccccccc}
\hline \multirow{2}{*}{ Location } & \multicolumn{7}{c}{ Activity concentration in soil samples $\left(\mathbf{B q} \mathbf{~ k g}^{-1}\right)$} \\
\cline { 2 - 7 } & ${ }^{40} \mathbf{K}$ & ${ }^{137} \mathbf{C s}$ & ${ }^{232} \mathbf{T h}$ & ${ }^{238} \mathbf{U}$ & ${ }^{226} \mathbf{R a}$ & ${ }^{210} \mathbf{P b}$ \\
\hline 1 & $431 \pm 3$ & $0.3 \pm 0.1$ & $42.8 \pm 0.8$ & $46 \pm 2$ & $36.5 \pm 0.5$ & $18 \pm 3$ \\
\hline 2 & $458 \pm 4$ & $7.6 \pm 0.3$ & $41.1 \pm 0.8$ & $49 \pm 3$ & $45.9 \pm 0.6$ & $78 \pm 9$ \\
\hline 3 & $474 \pm 4$ & $2.4 \pm 0.2$ & $37.2 \pm 0.8$ & $24 \pm 2$ & $35.2 \pm 0.5$ & $45 \pm 7$ \\
\hline 4 & $451 \pm 2$ & $2.6 \pm 0.1$ & $34.6 \pm 0.4$ & $33 \pm 1$ & $37.3 \pm 0.3$ & $32 \pm 3$ \\
\hline I & $501 \pm 4$ & $7.7 \pm 0.7$ & $43.8 \pm 0.6$ & $40 \pm 2$ & $45.4 \pm 0.4$ & $65 \pm 5$ \\
\hline II & $462 \pm 5$ & $2.4 \pm 0.2$ & $45.9 \pm 0.7$ & $49 \pm 1$ & $44.2 \pm 0.6$ & $37 \pm 4$ \\
\hline III & $539 \pm 4$ & $2.1 \pm 0.2$ & $44.7 \pm 0.8$ & $38 \pm 3$ & $48.1 \pm 0.6$ & $57 \pm 5$ \\
\hline
\end{tabular}

above the ground by ground sources has been reported elsewhere (16-18):

$$
\dot{E}=x_{\mathrm{K}} A\left({ }^{40} \mathrm{~K}\right)+x_{\mathrm{U}} A\left({ }^{238} \mathrm{U}\right)+x_{\mathrm{Th}} A\left({ }^{232} \mathrm{Th}\right)
$$

where $A$ is expressed in $\mathrm{Bq} \mathrm{kg}^{-1}$ and $\dot{E}$ in $\mathrm{J} \mathrm{kg}^{-1} \mathrm{~h}^{-1}$ [being either $\dot{D}$ or $\left.\dot{H}^{*}(10)\right]$. If $\dot{E}=\dot{D}$, then $x_{\mathrm{K}}=0.0417, x_{\mathrm{U}}=0.463$, and $x_{\mathrm{Th}}=0.604(16,17)$, and if $\dot{E}=\dot{H}^{*}(10)$, then $x_{\mathrm{K}}=0.0512$, $x_{\mathrm{U}}=0.564$, and $x_{\mathrm{Th}}=0.749$ (18). The values of $\dot{D}$ and $\dot{H}^{*}(10)$ calculated in this way for our samples are listed in Table 2. They show that the directly measured $\dot{H}^{*}(10)=80 \pm 15 \mathrm{nSv} \mathrm{h}^{-1}$ is almost entirely determined by the radioactive sources in the ground, and that the contribution of airborne radionuclides to $\dot{H}^{*}(10)$ is therefore very small.

Since the measured $\dot{H}^{*}(10)$ was dominated by soil radioactivity, the data for the $A$ of soil were sufficient to quantify the related radiological risk by calculating radium equivalent activity $\mathrm{Ra}_{\mathrm{eq}}$ and external hazard index $H_{\mathrm{ex}}$. According to Beretka and Mathew (19), the former quantity can be calculated from

$$
\mathrm{Ra}_{\mathrm{eq}}=A\left({ }^{226} \mathrm{Ra}\right)+1.43 A\left({ }^{232} \mathrm{Th}\right)+0.077 A\left({ }^{40} \mathrm{~K}\right)
$$

and the latter from

$$
H_{\mathrm{ex}}=\frac{A\left({ }^{226} \mathrm{Ra}\right)}{370}+\frac{A\left({ }^{232} \mathrm{Th}\right)}{259}+\frac{A\left({ }^{40} \mathrm{~K}\right)}{4810}
$$

where $A$ is expressed in $\mathrm{Bq} \mathrm{kg}^{-1}$. Radiological risk is considered to be low if $\mathrm{Ra}_{\mathrm{eq}}<370 \mathrm{~Bq} \mathrm{~kg}{ }^{-1}$ and $H_{\mathrm{ex}}<1$ (20, 21). Table 2 clearly shows that the $\mathrm{Ra}_{\mathrm{eq}}$ and $H_{\mathrm{ex}}$ of our four soil samples are well below these limits. Hence, the radiological risk due to external exposure to gamma radiation is low in Slavonski Brod.

For the time being, however, we do not have gamma-ray spectrometry readings for air samples - making them part of air monitoring in Slavonski Brod in future could prove useful - and we cannot properly assess the radiological risk due to inhalation. On the other hand, the measured $\dot{H}^{*}(10)$ mostly originated from the ground sources, suggesting that the air in Slavonski Brod has most likely not been strongly polluted with radioactive matter.

\section{CONCLUSION}

We found no evidence of radioactive pollution in Slavonski Brod that would deviate from the usual environmental radioactivity in this area. Therefore, whatever the source of other pollutants identified by regular monitoring, this pollution has not been accompanied by a hazardous release of radioactive matter into the environment.

\section{REFERENCES}

1. Upravni odjel za graditeljstvo, prostorno uređenje i zaštitu okoliša. Izvješće o razinama onečišćenosti i ocjeni kvalitete zraka u Slavonskom Brodu 2014. godine [Report on the pollution level and the assessment of air quality in Slavonski Brod for the year 2014, in Croatian]. Slavonski Brod: Executive Committee for Civil Engineering, Landscaping, and Environmental Protection; 2015.

Table $2 \dot{D}, \dot{H}^{*}(10), R a_{e q}$ and $H_{e x}$ calculated from the activity concentrations of our soil samples

\begin{tabular}{ccccc}
\hline Location & $\dot{\boldsymbol{D}}\left(\mathbf{n G y ~ h} \mathbf{-}^{-1}\right)$ & $\dot{\boldsymbol{H}}^{*}(\mathbf{1 0})\left(\mathbf{n S v ~ h} \mathbf{h}^{-1}\right)$ & $\mathbf{R a}_{\text {eq }}\left(\mathbf{B q ~} \mathbf{~ k g}^{-1}\right)$ & $\mathbf{H}_{\text {ex }}$ \\
\hline 1 & 65.2 & 80.1 & 131 & 0.35 \\
\hline 2 & 66.6 & 81.9 & 140 & 0.38 \\
\hline 3 & 53.5 & 65.9 & 125 & 0.34 \\
\hline 4 & 54.9 & 67.5 & 122 & 0.33 \\
\hline I & 69.8 & 85.8 & 147 & 0.40 \\
\hline II & 69.7 & 85.7 & 146 & 0.39 \\
\hline III & 67.1 & 82.5 & 154 & 0.41 \\
\hline
\end{tabular}


2. Upravni odjel za graditeljstvo, prostorno uređenje i zaštitu okoliša. Izvješće o razinama onečišćenosti i ocjeni kvalitete zraka u Slavonskom Brodu 2015. godine. [Report on the pollution level and the assessment of air quality in Slavonski Brod for the year 2015, in Croatian]. Slavonski Brod: Executive Committee for Civil Engineering, Landscaping, and Environmental Protection; 2016.

3. Upravni odjel za graditeljstvo, prostorno uređenje i zaštitu okoliša. Izvješće o razinama onečiščenosti i ocjeni kvalitete zraka u Slavonskom Brodu 2016. godine. [Report on the pollution level and the assessment of air quality in Slavonski Brod for the year 2016, in Croatian]. Slavonski Brod; Executive Committee for Civil Engineering, Landscaping, and Environmental Protection; 2017.

4. Gvozdić V, Brana J, Malatesti N, Puntarić D, Vidosavljević D, Roland D. An analysis of the pollution problem in Slavonski Brod (Eastern Croatia). Coll Antropol 2011;35:1135-41. PMID: 22397250

5. Bakr WF. Assessment of the radiological impact of oil refining industry. J Environ Radioact 2010;101:237-43. doi: 10.1016/j.jenvrad.2009.11.005

6. Marović G, Avdić M, Babić D, Bituh T, Branica G, Franić Z, Franulović I, Kolar M, Petrinec B, Petroci Lj, Senčar J, Skoko B, Šoštarić M. Praćenje stanja radioaktivnosti životne sredine u Republici Hrvatskoj, godišnji izvještaj 2013 [Results of environmental radioactivity monitoring in the Republic of Croatia, annual report for 2013, in Croatian]. Zagreb: Institute for Medical Research and Occupational Health; 2014.

7. Marović G, Avdić M, Babić D, Bituh T, Branica G, Franić Z, Franulović I, Kolar M, Petrinec B, Petroci Lj, Senčar J, Skoko B, Šoštarić M. Praćenje stanja radioaktivnosti životne sredine u Republici Hrvatskoj, godišnji izvještaj 2014 [Results of environmental radioactivity monitoring in the Republic of Croatia, annual report for 2014, in Croatian] Zagreb: Institute for Medical Research and Occupational Health; 2015.

8. Marović G, Avdić M, Babić D, Bituh T, Branica G, Franić Z, Franulović I, Kolar M, Petrinec B, Petroci Lj, Senčar J, Skoko B, Šoštarić M. Praćenje stanja radioaktivnosti životne sredine u Republici Hrvatskoj, godišnji izvještaj 2015 [Results of environmental radioactivity monitoring in the Republic of Croatia, annual report for 2015, in Croatian]. Zagreb: Institute for Medical Research and Occupational Health; 2016.

9. Marović G, Avdić M, Babić D, Bituh T, Branica G, Franić Z, Franulović I, Kolar M, Petrinec B, Petroci Lj, Senčar J, Skoko B, Šoštarić M. Praćenje stanja radioaktivnosti životne sredine u Republici Hrvatskoj, godišnji izvještaj 2016
[Results of environmental radioactivity monitoring in the Republic of Croatia, annual report for 2016, in Croatian]. Zagreb: Institute for Medical Research and Occupational Health; 2017.

10. Mirion Technologies (RADOS) Health Physics Division. RDS-31 S/R Multi-Purpose Survey Meter User's Manual, Doc No: 2096 6082. Ver: 2.1 [displayed 3 August 2017]. Available at http://www.laurussystems.com/Service/ RDS_31_MANUAL.pdf

11. Harley JJ. HASL Procedures Manual. USAEC Report HASL300. 1970.

12. International Atomic Energy Agency (IAEA). Measurement of Radionuclides in Food and the Environment, A Guidebook. Technical Reports Series No. 295. Vienna: IAEA; 1989.

13. Petrinec B, Franić Z, Bituh T, Babić D. Quality assurance in gamma-ray spectrometry of seabed sediments. Arh Hig Rada Toksikol 2011;62:17-23. doi: 10.2478/10004-1254-62-20112078

14. Šoštarić M, Babić D, Petrinec B, Zgorelec Ž. Determination of gamma-ray self-attenuation correction in environmental samples by combining transmission measurements and Monte Carlo simulations. Appl Radiat Isot 2016;113:110-6. doi: 10.1016/j.apradiso.2016.04.012

15. Vidmar T. EFFTRAN - A Monte Carlo efficiency transfer code for gamma-ray spectrometry. Nucl Instrum Methods Phys Res A 2005;550:603-8. doi: 10.1016/j.nima.2005.05.055

16. Saito K, Jakob P. Gamma ray fields in the air due to sources in the ground. Radiat Prot Dosim 1995;58:29-45. doi: 10.1093/oxfordjournals.rpd.a082594

17. United Nations Scientific Committee on the Effects of Atomic Radiation. Sources and Effects of Ionizing Radiation. New York (NY): United Nations; 2000.

18. Lemercier M, Gurriaran P, Bousset P, Cagnat X. Specific activity to $H^{*}(10)$ conversion coefficients for in situ gamma spectrometry. Radiat Prot Dosim 2008;128:83-9. doi: 10.1093/rpd/ncm307

19. Beretka J, Mathew PJ. Natural radioactivity of Australian building materials, industrial wastes and by-products. Health Phys 1985;48:87-95. PMID: 3967976

20. Szabó Z, Völgyesi P, Nagy HÉ, Szabó C, Kis Z, Csorba O. Radioactivity of natural and artificial building materials - a comparative study. J Environ Radioact 2013;118:64-74. doi: 10.1016/j.jenvrad.2012.11.008

21. Farai IP, Ademola JA. Radium equivalent activity concentrations in concrete building blocks in eight cities in Southwestern Nigeria. J Environ Radioact 2005;79:119-25. doi: 10.1016/j.jenvrad.2004.05.016 


\section{Trenutačno radiološko stanje u Slavonskom Brodu - ima li razloga za brigu?}

Godinama se hrvatski grad Slavonski Brod suočava s ozbiljnim problemom zagađenosti zraka, koji se povezuje s rafinerijom nafte u susjednoj Bosni i Hercegovini. Rafinerija se nalazi u neposrednoj blizini grada, a od grada ju odjeljuje rijeka Sava. U gradu se provode detaljna mjerenja kvalitete i zagađenosti zraka, a radiološkoj komponenti zagađenosti dosad nije pridavana pozornost. U ovom su radu prikazani rezultati prvog istraživanja koje se odnosi na radiološku komponentu zagađenosti okoliša. Provedena su mjerenja brzine ambijentalnog doznog ekvivalenta na 150 lokacija. Mjerene vrijednosti ne prelaze $120 \mathrm{nSv} \mathrm{h}^{-1}$, a njihova srednja vrijednost iznosi $80 \mathrm{nSv} \mathrm{h}^{-1}$. Gamaspektrometrijska mjerenja uzoraka vode iz rijeke Save i uzoraka tla s područja grada ne pokazuju povišene vrijednosti radioaktivnosti. Drugim riječima, nije pronađen trag koji bi upućivao na radiološku zagađenost opasnu za zdravlje građana.

KLJUČNE RIJEČI: brzina ambijentalnog doznog ekvivalenta; gamaspektrometrija; kvaliteta zraka; radiološko zagađenje; rafinerija nafte 